\title{
Cosmovisión nonuya e imagen poscolonial en el arte colombiano: una mirada a la obra de Abel Rodríguez
}

\author{
Nonuya Worldview and Postcolonial Image in Colombian Art: \\ a Look at the Work of Abel Rodriguez
}

Artículo recibido el I5 de diciembre de 20I6; devuelto para revisión el I4 de marzo de 20I7; aceptado el 2I de mayo de 20I7, http://dx.doi.org/IO.2220I/iie.18703062e.20I7.III.2608

\author{
Jorge Lopera Gómez Universidad EAfit, Medellín, Colombia \\ jlopera9@eafit.edu.co, loperagomezj@gmail.com
}

Publicaciones más relevantes Libro en coautoría con Viviana Palacio, Museo de Arte Moderno de Medellin: breve historia (Medellín: Mesaestándar, 2016); "Procesos de creación en arquitectura o construcciones ilusorias: límites difusos en la obra del grupo Utopía”, Revista Co-herencia I2, núm. 22 (2015): 269276; en coautoría con Efrén Giraldo, "Ficción y proyectación: arquitectura e imagen en la obra del grupo Utopía (Medellín, 1979-2009)”, en ¿Arte sin estética? (Medellín: Universidad de Antioquia, 2016), 2II-244.

Juan Gonzalo Betancur Universidad EAfIT, Medellín, Colombia

Betancur jbetan38@eafit.edu.co

Publicaciones más relevantes Libro en coautoría con Kim Manresa, Los olvidados-Resistencia cultural en Colombia (Bogotá: Villegas Editores, 2004); "Conflicto armado interno versus amenaza terrorista: la disputa por un concepto", Reflexión Politica I2, fasc. 24 (2010): 68-77; "En la guerra, los periodistas fastidian”, Estudios Venezolanos de Comunicación, núm. I22 (2003): IO-I6; "Colombia, una guerra en 'contravía informativa”, Reflexión Política 4, fasc. 8 (2002): II8-I35.

Líneas de investigación Estudios culturales; estudios de narrativas; teoría e historia del arte en Colombia; estudios visuales.

Lines of research Cultural studies; studies on narratives; theory and history of art in Colombia; visual studies.

Resumen Este artículo propone una mirada a la obra de Abel Rodríguez, un indígena de la comunidad nonuya que ha contribuido mediante pinturas y dibujos a la comprensión de los ecosistemas sociales de la Amazonía colombiana, y que ha empezado a ser reconocido por la institucionalidad del arte contemporáneo mediante la participación en exposicio- 
nes en los ámbitos nacional e internacional. Esta contribución aborda la relación entre la cosmivisión nonuya y la forma de participar de Abel Rodríguez en el arte contemporáneo. Para este trabajo se revisan algunos relatos tradicionales representados por Rodríguez, se analiza la relación entre imagen y narración, y se considera su obra a la luz de los estudios culturales, el llamado "poscolonialismo" y la institucionalidad del arte, a sabiendas de que la emergencia de discursos "menores", como sucede en este caso, puede permitir nuevas discusiones en el arte contemporáneo.

Palabras clave Lenguas nativas de Colombia; arte colombiano contemporáneo; arte indígena; estudios culturales; poscolonialismo; imagen.

Abstract This text seeks to analyze the work of Abel Rodríguez, a native member of the Nonuya community who has contributed through his paintings and drawings to the understanding of social and ecological systems in the Colombian Amazon region. His work has begun to be recognized by the institutions of contemporary art via national and international exhibitions. This contribution addresses the relationship between the Nonuyas' world view and Abel Rodríguez's form of participation in contemporary art. Selected native tales are examined and the relationship between image and narration is analyzed. His work is considered from a cultural studies approach, in the light of so-called "post-colonialism" and art institutionalism, in the understanding that the emergence of "minor" discourses, as is the case here, generates new discussions in contemporary art theory.

Keywords Native languages of Colombia; Colombian contemporary art; indigenous art; cultural studies; postcolonialism; image. 


\author{
JORGE LOPERA GÓMEZ \\ JUAN GONZALO BETANCUR BETANCUR \\ UNIVERSIDAD EAFIT, COLOMBIA
}

\title{
Cosmovisión nonuya e imagen poscolonial en el arte colombiano:
} una mirada a la obra de Abel Rodríguez

Yo soy muy tranquilo por todo. No me preocupo ni me afano ni me siento derrotado por nada. Espero que pasen los tiempos. Llegará el momento.

Abel Rodríguez

\footnotetext{
Tuentan los relatos de las comunidades indígenas que habitan cerca de los ríos Amazonas, Mirití-Paraná y Caquetá que en el origen de los tiempos había un Árbol Río que dio origen al mundo del agua. Del árbol se derivaron tres ríos: uno que vuela, otro que corre caudalosamente sobre la tierra y uno que corre de manera subterránea. El mito se refiere al río Amazonas.

De acuerdo con la mitología nonuya, ${ }^{\mathrm{I}}$ en un principio el territorio amazónico estaba habitado por los cuatro seres creadores y su tía, quien al ser la única

I. El pueblo nonuya vive en el suroriente de Colombia, en el departamento del Amazonas. Fueron una cultura numerosa, pero la llegada del auge de la extracción del caucho entre finales del siglo xIx y comienzos del xx llevó a que se les esclavizara y a que sufrieran toda clase de vejámenes. Eso provocó el desplazamiento de su territorio y una disminución drástica de su población. Hoy, su lengua se encuentra en peligro de extinción ya que las tres personas que la hablaban plenamente ya fallecieron. Dos adultos - uno de ellos Abel Rodríguez-y dos jóvenes tienen competencia y conocimiento sobre esta lengua, aunque limitado. Véase Juan A. Echeverri e Isabel V. Romero, "Agonía y revitalización de una lengua y un pueblo: los nonuya del Amazonas", Forma y Función, núm. 29 (2016): 135-156.
} 
con acceso directo al agua era mezquina con el líquido vital haciéndoles creer a sus sobrinos que la poca que tenía la recolectaba todas las noches de las gotas de los árboles frondosos que cubrían la selva. Un día, el menor de los cuatro hermanos decidió convertirse en murciélago para descubrir de dónde obtenía la tía el agua y se dio cuenta de que provenía de un árbol. Voló al encuentro de los otros tres, ante quienes develó el misterio descubierto.

Los hermanos decidieron tumbar el árbol con un hacha para dejar el agua en este mundo. Cuando lograron derribarlo, no cayó al suelo: quedó colgando de bejucos que lo sostenían desde el cielo. De acuerdo con el relato, si no hubiera quedado colgando, no se hubieran formado las nubes ni las corrientes que hacen que llueva sobre el Amazonas. Este sistema aéreo recibió el nombre de "El río que vuela". El relato cuenta también que al principio el árbol estuvo colgado hacia el Occidente y luego se volteó hacia el Oriente, es decir, que el río Amazonas corrió primero hacia el Occidente y luego invirtió su rumbo. ${ }^{2}$

Los cuatro hermanos enviaron una ardilla para cortar los bejucos, pues dentro de las especies que habitaban el territorio ésta era veloz y tenía los dientes bastante afilados. La tía les advirtió la necesidad de construir un soporte en el piso para que al caer el árbol no siguiera hacia las profundidades de la Tierra. Los cuatro, entonces, construyeron una estructura endeble que no resistió. Por ello, éste se hundió en lo más hondo y dio origen a un río que corre de manera subterránea. ${ }^{3}$ Entre uno y otro, sobre la superficie de la Tierra, finalmente se formó, asemejando la forma de una serpiente, el río Amazonas.

2. Este relato mítico tiene una correspondencia en hallazgos científicos que confirman varias de las ideas presentes en el cuento nonuya: estudios geológicos han demostrado que en el Mioceno Medio y Mioceno Superior, antes de que surgiera la cordillera de los Andes, el río Amazonas desembocaba en el océano Pacífico y luego de que emergieran los Andes cambió su dirección y empezó a desembocar en el Atlántico. Si bien el relato fantástico resulta poco creíble, la teoría científica de algún modo valida el conocimiento tradicional que, a través de los relatos orales, llevaba a las comunidades amazónicas a pensar que el río en algún momento invirtió su rumbo. Véase Parque Explora, "El Árbol Río", consultado el 5 de agosto de 20I6, en https://www.youtube. com/watch?v=ENrKxizAs_o.

3. Un estudio de los profesores brasileños Elizabeth Tavares Pimentel y Valiya Hamza, publicado en 20II, demostró la existencia de una corriente de agua que fluye entre las rocas porosas debajo del río Amazonas a una velocidad de Ioo metros por año, lo que ha suscitado numerosas discusiones acerca de la existencia real de un río subterráneo que podría considerase como el más grande del mundo. Véase Elizabeth Tavares Pimentel y Valiya Hamza, "Indications of an Underground River Beneath the Amazon River: Inferences from Results of Geothermal Studies", conferencia presentada en el XII Congreso Internacional de la Sociedad de Geofísica de Brasil, llevado a cabo en Río de Janeiro, del I5 al I8 de agosto, 2011. 
Esta cosmovisión de la formación del mundo acuático expresada en el mito nonuya ha sido parte de las representaciones que Abel Rodríguez ha realizado en tinta china. Este hombre nació en la pequeña población de La Chorrera en 194I y es miembro de la comunidad Peña Roja, de los resguardos Villazul de la etnia nonuya, en el departamento colombiano de Amazonas. Desde finales de la década de los ochenta se convirtió en colaborador de las investigaciones que lleva a cabo la organización Tropenbos Internacional Colombia. ${ }^{4}$ Mediante proyectos desarrollados por Tropenbos sobre la botánica del Amazonas, la clasificación local de árboles y plantas, sus usos, los ciclos de cultivo y las relaciones sociales que esto implica, Rodríguez encontró en la pintura una forma de plasmar su conocimiento, una producción visual que hoy suma más de 400 ilustraciones de árboles y plantas. ${ }^{5}$

Rodríguez pertenece al clan Gavilán de los nonuya y su nombre original es Mogaje Guiju, que traduce "el resplandor de las plumas del gavilán bajo el sol". El idioma de este grupo indígena constituye una de las cinco lenguas nativas de Colombia definidas como "moribundas", ${ }^{6}$ la clasificación más dramática

4. La Fundación Tropenbos Colombia es una ONG holandesa que aboga por la conservación y el manejo sostenible de los bosques tropicales. Durante varias décadas ha realizado proyectos de investigación con comunidades indígenas en la selva amazónica colombiana.

5. Pese a que al inicio de la cooperación con Tropenbos el papel de Rodríguez era en gran medida ayudar a la investigación de los ecosistemas de la Amazonía, específicamente como guía y sabedor de los usos y los nombres de las plantas, años después Rodríguez empezaría, por sugerencia de Carlos Rodríguez, director de Tropenbos, a realizar dibujos basados en el conocimiento que tenía del territorio. Como el mismo artista recuerda, al principio la mano le temblaba y las líneas se torcían, y fueron muchos los ensayos que tuvo que hacer con diferentes técnicas, entre ellas dibujos con lápices de color, acuarela y acrílico, hasta que eligió la tinta china. De este modo, el aprendizaje y afianzamiento del dibujo, en su caso, fueron posibles gracias a la experimentación, tal y como sucedió con el aprendizaje sobre las plantas. Véase ;Mira! Artes visuales contemporáneas de los pueblos indígenas, "Abel Rodríguez", entrevista realizada al artista en abril de 20I4, consultada el I7 de agosto de 20I6, en www.youtube.com/watch?v=XGexoCeG2vU.

6. Las otras lenguas "moribundas", según la denominación del lingüista y filósofo Jon Landaburu, uno de los más prestigiosos estudiosos de las lenguas nativas de Colombia, son la tinigua (con dos hablantes), carijona (se calcula unos 30 hablantes pasivos, es decir, que la comprenden pero no la hablan ni la utilizan en ningún espacio), totoró (con cuatro hablantes activos y unos 50 pasivos) y pisamira (se calculan unos 25 hablantes). La Unesco clasifica a la nonuya como "críticamente en peligro”. Véase Jon Landaburu, Clasificación de las lenguas indígenas de Colombia (Bogotá: Centro Colombiano de Estudio de Lenguas Aborígenes y Universidad de Los Andes, 1999, I0-25); Jon Landaburu, "Las lenguas indígenas de Colombia: presentación y estado del arte," en Amerindia, núms. 29/30II (2004-2005); Unesco, "Unesco Atlas of the World's Languages in Danger", consultado el ir de agosto de 20I6, en www.unesco.org/culture/languages-atlas/index.php. 
para las 4I lenguas, de 68 que tiene el país, que están en peligro de extinción. ${ }^{7}$ Desde niño aprendió y practicó conocimientos acerca de los tipos de plantas, usos y ubicación, una muestra de la relación que las comunidades indígenas establecen con el entorno que habitan. Los dibujos de Rodríguez dan cuenta de los conocimientos de la comunidad nonuya sobre los sistemas propios de la selva amazónica, una representación posible gracias a su memoria. Su capacidad artística no se limita a representaciones bidimensionales, sino que también tiene trabajos de cestería tradicional que diferencia dos tipos de canastos: unos que se hacen para uso diario y otros que se fabrican con más cuidado, poseen más detalle y cargan contenidos simbólicos, que sirven como intercambio económico con otras personas.

A raíz del trabajo que ha realizado de la mano de Tropenbos, la obra de Rodríguez ha empezado a considerarse dentro de los circuitos del arte contemporáneo, como una manera de incluir relatos "menores" artes plásticas y visuales. El presente texto revisa la manera en que el trabajo de Rodríguez se ha hecho visible en los últimos años a partir de exposiciones nacionales e internacionales, y las implicaciones que esto tiene dentro de la historiografía y la teoría del arte. ${ }^{9}$ Podríamos señalar en este punto varias situaciones:

I) La validación de una producción estética proveniente de alguien ajeno a los circuitos artísticos tradicionales, un hecho que sugiere la emergencia de actores que normalmente han sido invisibilizados por el discurso oficial y que, de acuerdo con el crítico, historiador y curador cubano

7. Según Landaburu, en una entrevista realizada por los autores en noviembre de 2015 , la escala de peligrosidad para estas lenguas en Colombia es: en peligro potencial 20 de ellas, en peligro II, en serio peligro 4 y moribundas 5. En 2009, la Corte Constitucional de Colombia, mediante el Auto 004, demandó del Estado colombiano atención especial y medidas de protección para 34 pueblos indígenas que consideró “en situación de alto riesgo". En 20Io, la Organización Nacional Indígena de Colombia (ONIC) lanzó una campaña internacional por la supervivencia de 32 grupos étnicos o pueblos indígenas "en peligro de extinción" (onU-Derechos Humanos).

8. El término ha sido utilizado por Gilles Deleuze y Félix Guattari (Kafka por una literatura menor [México: Era, 1978], 28), para referirse, dentro de los estudios literarios, a un tipo de literatura que no se inscribe en las corrientes dominantes y que viven en la extrañeza de la lengua. De acuerdo con los autores: "Una literatura menor no es la literatura de un idioma menor, sino la literatura que una minoría hace dentro de una lengua mayor." El uso del término se ha extrapolado a otros campos de conocimiento, entre ellos el arte, de tal modo que la situación que tiene lugar en el caso de Abel Rodríguez puede emparentarse con la idea de un relato menor dentro de la teoría y la historia del arte contemporáneo, gracias al discurso que sirve de trasfondo a sus pinturas.

9. La obra de Rodríguez se ha presentado, entre otras, en: la Biblioteca Luis Ángel Arango en Bogotá; la exposición Historia natural y política: conocimientos y representaciones de la naturaleza 
Gerardo Mosquera, hace parte de las nuevas dinámicas que tienen lugar en la internacionalización del arte contemporáneo. ${ }^{10}$

2) La relación entre narración e imagen, objeto de estudio en los últimos años en los campos de la estética, la historia y la teoría del arte, que se hace presente en gran parte del trabajo de Abel.

3) La confluencia de circunstancias que refieren a una situación del arte que puede emparentarse con las teorías poscoloniales y los estudios culturales.

La presencia de Abel Rodríguez en el campo del arte hace visible un relato menor dentro de la historia del arte colombiano. En él confluyen otros casos aislados que aún se mantienen al margen de las instituciones artísticas y que todavía operan bajo la premisa del arte como una práctica íntimamente ligada a la experiencia vital, un rasgo que es por demás común en las comunidades indígenas por medio de la cosmovisión que han establecido acerca del universo y en consecuencia de la existencia misma. ${ }^{\text {II }}$

\section{La mirada directa del mundo: conocimiento y manifestación artística}

La marginalidad a la que han estado sometidos los pueblos indígenas desde el periodo de la colonia es una constante que sigue presente en la realidad latinoa-

americana (2009) en el Centro Cultural Biblioteca Luis Echavarría de la Universidad EAFIT (Medellín); el 43 Salón (inter) Nacional de Artistas (20I3); la exposición Selva cosmopolitica (2014) en el Museo de Arte de la Universidad Nacional de Colombia; la exhibición "Waterweavers: The River in Contemporary Colombian Visual and Material Culture" (2014) en el Bard Graduate Center de Nueva York; y la exposición "La vorágine" (2015) en la Galería OMR en la Ciudad de México, una de las más relevantes de ese país.

Io. Gerardo Mosquera, "Adiós a la antropofagia. Arte, internacionalización y dinámicas culturales", conferencia dictada en el Museo Banco de la República de Bogotá, consultado el 25 de julio de 2016, en www.youtube.com/watch?v=loXligBNPyo.

II. En 20I4, Abel Rodríguez ganó el premio principal Prince Claus, otorgado por la fundación homónima, que premia a personas o instituciones que contribuyen al desarrollo o la cultura contemporánea. Su reconocimiento se debe, entre otras cosas, a la función que ha cumplido como mediador en el conocimiento de los sistemas ecosociales del Amazonas con Tropenbos, un proceso en el que ha dado a conocer la visión del mundo indígena como fuente de conocimiento para el bien común. El intercambio cultural que suscita este tipo de proyectos, donde convergen el mythos propio de las comunidades indígenas y el logos perteneciente a las investigaciones científicas occidentales, ha ocurrido en un contexto en el que la discriminación y la violencia han sido constantes. 
mericana. Las vías que se han buscado para preservar los valores culturales de las comunidades nativas han sido múltiples, en especial desde la segunda mitad del siglo xx. No obstante, por fuera de cualquier estrategia estatal o gubernamental, dentro de la comunidad nonuya, uno de sus habitantes ha documentado mediante la imagen pictórica la cosmovisión y el conocimiento botánico y medicinal de esta cultura. Debe señalarse que las manifestaciones pictóricas de comunidades nativas han correspondido a la manera particular en la que ven el mundo, algo que guarda una estrecha relación con el carácter vital, inherente a la práctica del arte. De acuerdo con el historiador alemán Hans Belting, muchas de estas imágenes constituyen actos sociales que corresponden de manera simétrica tanto a la percepción como a la representación de la existencia, y están relacionadas con interrogantes acerca de la identidad colectiva. ${ }^{\text {I2 }}$

Pensar la obra de Abel Rodríguez en esta vía implica reconocer que, en tanto miembro de una comunidad amazónica, su percepción de la vida nativa conlleva inevitablemente a la producción de imágenes en las que los relatos indígenas se hacen presentes a través de un medio como la pintura. De hecho, ésta ha sido la razón para que sus pinturas se consideren como una forma de documentar el conocimiento tradicional de la comunidad nonuya. En su obra, tal conocimiento ha estado centrado en la naturaleza del entorno vital. Ahí, la imagen es resultado de un proceso doble: por un lado, se encuentra la mirada que recae sobre la realidad inmediata y, por otro, la asignación de sentido o "imagen mental” que surge al cargar simbólicamente la visión del mundo con los mitos y relatos tradicionales del conocimiento indígena. Belting otorga a esta condición un carácter antropológico y lo advierte así:

La duplicidad del significado de las imágenes internas y externas no puede separarse del concepto de imagen [...]. Una imagen es más que un producto de la percepción. Se manifiesta como resultado de una simbolización personal o colectiva. Todo lo que pasa por la mirada o frente al ojo interior puede entenderse así como una imagen o transformarse en una imagen. Debido a esto si se considera seriamente el concepto de imagen, únicamente puede tratarse de un concepto antropológico. ${ }^{13}$

La acción creadora de las imágenes de Rodríguez, si bien responde a la percepción inmediata, cumple también un papel fundamental para las lectu-

I2. Hans Belting, Antropología de la imagen, trad. Gonzalo María Vélez Espinosa (Madrid: Katz Editores, 2009), 8.

13. Belting, Antropología de la imagen, I4. 
ras culturales y antropológicas. Las imágenes adquieren un carácter medial al insertarse en contextos sociales ajenos al origen de las pinturas, especialmente cuando se presentan tanto en el contexto de las investigaciones científicas de Tropenbos como en los circuitos del arte contemporáneo. Además recurren a un medio tradicional en un momento histórico en el que el arte explora nuevos horizontes de creación con la experimentación de múltiples medios. Aunque la pintura se ha actualizado y ha seguido su curso en la historia del arte reciente, los dibujos de Rodríguez muestran la pintura en su expresión más primaria: como recurso que representa el mundo de la vida cotidiana y que busca explicar los fenómenos cercanos a la existencia de un pueblo indígena. En su trabajo, más que la intención de ingresar en el campo artístico, prima la elaboración de imágenes como un documento que expone los saberes tradicionales y fija un lenguaje producto de las tradiciones orales. De este modo, el medio en el que realiza la imagen y la forma en la que la produce, escapa a cualquier tentativa de relacionarla con los cánones establecidos por la historia y la teoría del arte. Podría decirse que en el trabajo de Abel la imagen opera, desde su gesto, más como una suerte de transparencia simbólica — gracias a la simetría entre la representación y el conocimiento indígena- que como una actitud autorreflexiva sobre los problemas del arte. Las imágenes son resultado de actos de enunciación: mitos y conocimientos que han pasado de generación en generación, y que remiten a una verdad superior, tal y como sucede en El árbol de la abundancia y la gente (fig. I).

Una de sus pinturas, titulada Territorio centro (fig. 2), muestra un fragmento de la selva amazónica vista desde arriba. En la imagen puede notarse un río que corre a lo largo del dibujo y en el que confluye otro afluente más tenue que proviene de la parte superior. Ambos ríos hacen parte de un tapete verde, uniforme, en el que también aparecen árboles de gran altura que tienen valor para las comunidades nativas por los usos que se derivan de sus hojas y cortezas. En este sentido, las pinturas realizadas por Rodríguez son a su vez cartografías que presentan un territorio desde sus múltiples dimensiones: temporal, simbólica o de interacción social. Su figura se acerca más a la de un etnógrafo que a la de un artista que busca hacer mapas con condiciones estéticas que le permitan ingresar en los espacios de presentación del arte, toda vez que el proceso de representación parte del despliegue de su existencia en la selva amazónica, esto es, de su contacto con un territorio específico. En su caso, el trabajo se asemeja al de los ilustradores de relatos de viaje de los siglos XVIII y XIX, que en un intento por documentar la realidad y traducir en imágenes los hallazgos de 


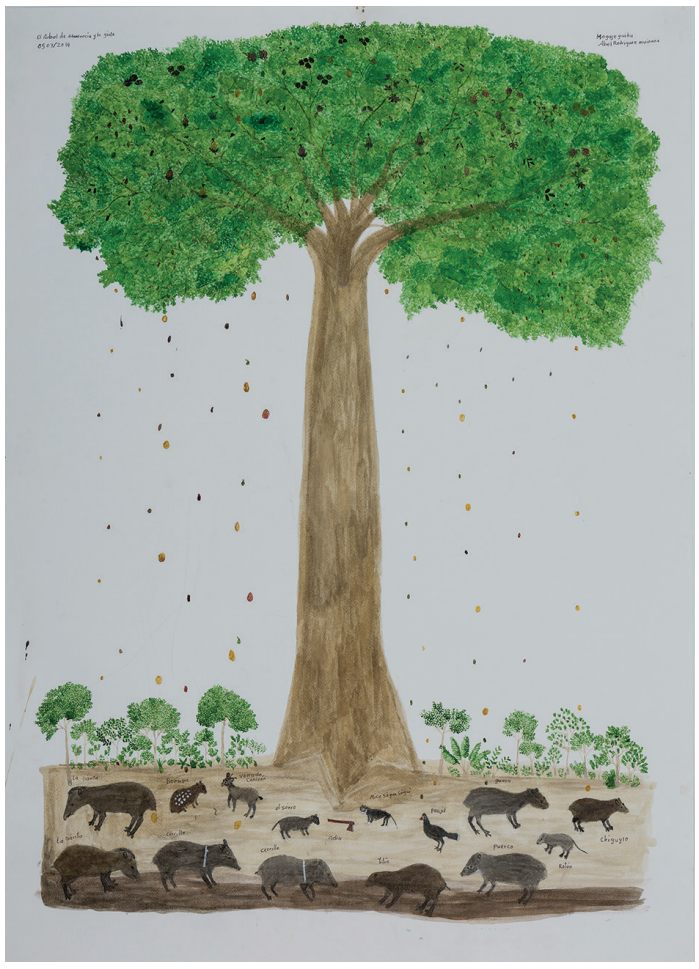

I. Abel Rodríguez, El árbol de la abundancia y la gente, 20I4, tinta china sobre papel, $100 \times 70 \mathrm{~cm}$. Imágen cortesía de Óscar Roldán Alzate.

las ciencias, dibujaban plantas, lugares geográficos y mapas con un interés que se inscribía claramente en el ejercicio de clasificación moderno.

Sin embargo, de acuerdo con el curador sueco Jan-Erik Lundström, "tras declarar que el mapa produce territorio, el siglo XXI sigue produciendo cartografías críticas emergentes con modelos alternativos o revisionistas de creación de mapas". ${ }^{14}$ Esta perspectiva no se aleja del contenido que tiene el trabajo de Rodríguez, que por momentos alude a series de ilustraciones botánicas, en otros se refiere a los mitos fundacionales del conocimiento indígena, y en otras ocasiones refiere a secuencias de imágenes en las que se aprecia la temporalidad de los bosques tropicales de la Amazonía colombiana. Cada una de estas versiones

I4. Jan-Erik Lundström, "Haz un mapa”, en Saber desconocer. 43 Salón (inter) Nacional de Artistas, t. II: Libro de creencias (Bogotá: Ministerio de Cultura de Colombia, 20I4), 308. 


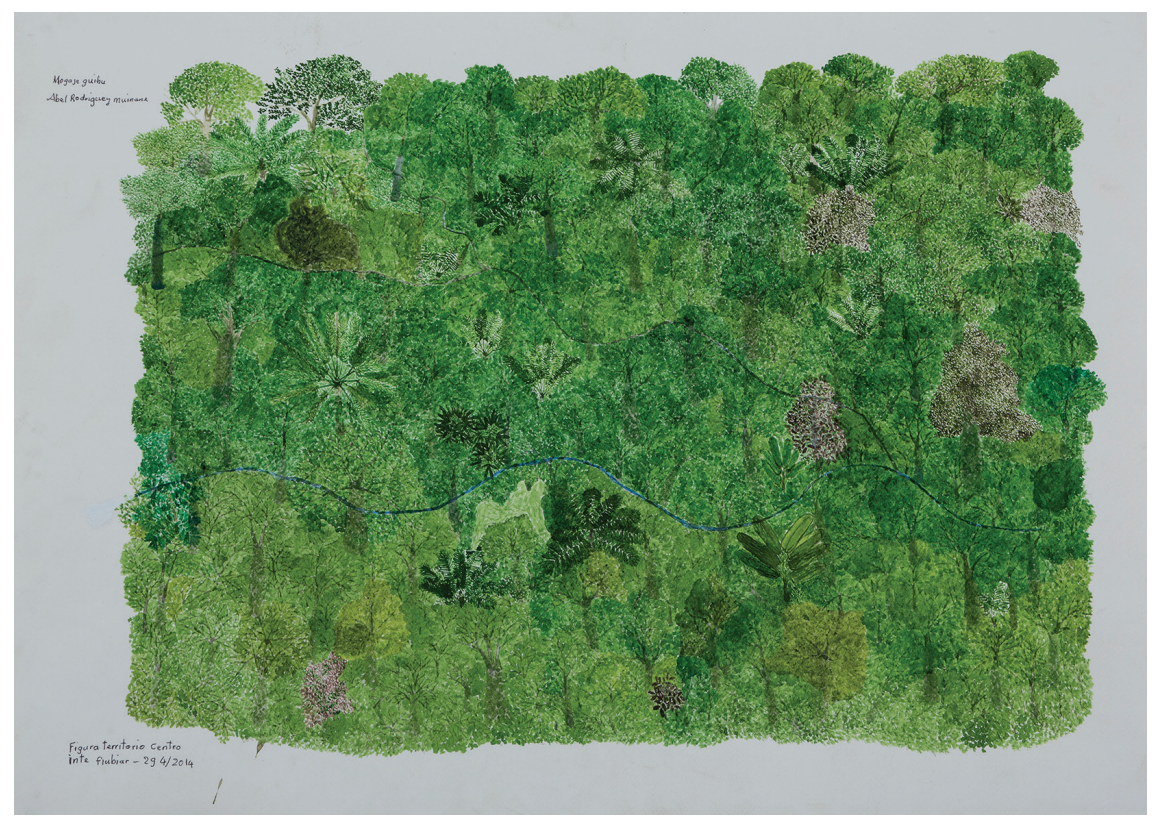

2. Abel Rodríguez, Territorio centro, 20I4, tinta china sobre papel, $50 \times 70 \mathrm{~cm}$. Imagen cortesía de Óscar Roldán Alzate.

muestra el territorio no a partir de una idea tradicional de "mapa" que sirve para ubicarse espacial y geográficamente, sino desde una perspectiva ampliada en la cual se presentan las diferentes condiciones que lo componen. Podría decirse que la dimensión simbólica derivada de las narraciones nativas sobrepasa por momentos el plano físico al que alude el mapa. Si las cartografías han sido herramientas de lectura del territorio, ya no sólo como lugar físico sino también como soporte gráfico que remite a las interacciones sociales de una comunidad con su entorno, los límites entre la representación física y mental de la comunidad nonuya confluyen, en el caso de Rodríguez, en cada una de las imágenes que crea gracias a su experiencia vital en la Amazonía. Esta situación, retomando los argumentos de Hans Belting, hace que la imagen tenga un carácter eminentemente antropológico.

Desde esta perspectiva, otra obra que da cuenta del conocimiento de los procesos que se llevan a cabo por las comunidades nativas es la serie Chagra 


\section{LOPERA GÓMEZ / BETANCUR BETANCUR}

(véase figs. 3-6), en la que cuatro pinturas evidencian, cada una con un intervalo de seis meses, el cambio de un tipo de cultivo que es frecuente en la Amazonía colombiana. El cultivo y la siembra, como acciones propias de las comunidades de esta región, tienen en la agricultura itinerante o chagra una forma de interactuar con los ecosistemas. De acuerdo con los investigadores Jesús Hernán Giraldo y Myriam Constanza Yunda, la chagra forma parte fundamental de la subsistencia de las familias indígenas:

La agricultura itinerante o chagra es hecha por la familia indígena mediante la selección del sitio, tumba selectiva del bosque, dejando en pie las palmas y árboles frutales que son de interés e importancia para su alimentación, quema del material derribado, siembra y establecimiento de varias especies vegetales nativas y propias de la región de periodos vegetativos semestrales, anuales y perennes, limpieza, recolección y abandono. La biodiversidad mantenida y establecida en la chagra es una herencia cultural que hace parte de la identidad de cada familia. Su función es garantizar la alimentación y subsistencia de la familia indígena, constituyendo parte esencial de la seguridad alimentaria de ésta, complementando las actividades de recolección, caza y pesca. ${ }^{\text {Is }}$

El proceso de la chagra, documentado por Rodríguez, sugiere también un cambio paulatino en la experiencia de las comunidades respecto al paisaje. El lugar en el que se realiza la tala selectiva elimina primero la vegetación abundante para dar paso al crecimiento de cultivos en un periodo de al menos un año y medio. Rodríguez muestra con claridad los cambios que se hacen visibles cuando la diferencia temporal alcanza los seis meses. En las pinturas se advierte la presencia de árboles que resultan relevantes para la mitología nonuya, y la coincidencia una vez más del conocimiento tradicional y el relato mítico (figs. 3-6). ${ }^{16}$

Pese a que en gran parte ha sido el trabajo pictórico de Rodríguez del que se ha ocupado el mundo del arte, debe señalarse que la manifestación de la

I5. Jesús Hernán Giraldo y Myriam Constanza Yunda, "La chagra indígena y biodiversidad: sistema de producción sostenible de las comunidades indígenas del Vaupés”, en Cuadernos de Desarrollo Rural (Bogotá: Pontificia Universidad Javeriana, 2000), 47.

I6. En un documental de 2005 del holandés Jan Willem Meurkens títulado From Inside Out, una de las escenas muestra el momento en que un indígena trata de tumbar un árbol para hacer una chagra. Del árbol sale gran cantidad de agua, una imagen semejante a la enunciada al inicio de este artículo en el mito del "Árbol Río". 


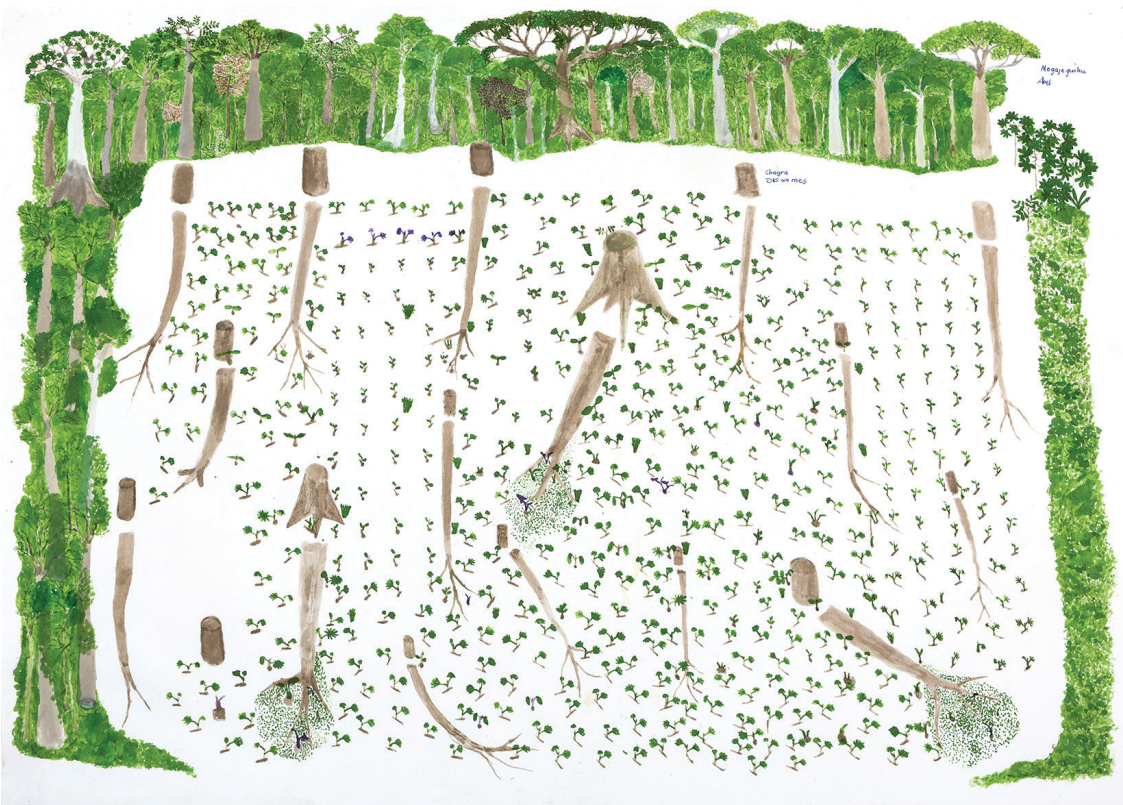

3. Abel Rodríguez, Chagra de un mes, de la serie Chagra, 2013, tinta china sobre papel, $50 \times 70$ cm. Imagen cortesía de Óscar Roldán Alzate.

cosmovisión nonuya tiene también en la producción tridimensional un punto de anclaje. Rodríguez es también experto en la cestería tradicional que incluye canastos, chinchorros, balays y cernidores ${ }^{17}$ Estas creaciones llegaron a la comunidad por medio de relatos mitológicos, como narra el artista en una entrevista realizada en 2013 por la Smithsonian Institution:

Hay que hacer canastos para empacar y transportar alimentos. Eso no es algo reciente, eso no lo inventó cualquiera, vino mitológicamente. Los canastos los inventó el creador a través de un hombre. En un sueño el espíritu le dijo al hombre: haga canastos para que su esposa pueda colar la masa, y a partir de allí se empezó a realizar este tipo de artesanía. ${ }^{18}$

17. El chinchorro es una hamaca y el balay, una cesta de poca profundidad equivalente a un plato.

I8. SmithsonianFolklife, "Abel Rodríguez, Amazonian Basket Weaver", consultado el 5 de agosto de 20I6, en www.youtube.com/watch?v=gl_9GY_fwek 
A diferencia de lo que sucede en términos de preservación del conocimiento y de la cosmovisión nonuya en las imágenes bidimensionales, en el trabajo de cestería, exhibido en algunas de las muestras en las que ha participado Rodríguez, también se advierte una preservación de la cultura material de su comunidad. Mediante la presencia de trabajo artesanal en las exposiciones artísticas, los nonuya se hacen visibles, declaran su existencia y se representan como cultura; la exposición se convierte así en un lugar de enunciación. La artesanía entabla un diálogo con las pinturas y complementa su discurso desde objetos que remiten a las acciones sociales de la vida cotidiana de este pueblo indígena. ${ }^{19}$

Sea a través de la imagen o la cestería, la obra de Rodríguez llama la atención sobre la importancia del mito en la construcción de una visión del universo. Esta cuestión puede emparentarse con los estudios realizados por el teórico Adolfo Colombres, en tanto que para el autor argentino el mito es un fundamento en la configuración de la verdad:

El mito, como el lenguaje, configura un campo de posibilidades y prohibiciones. No se trata, como se cree vulgarmente, de una ficción, de una fantasía, desde que representa una traducción al imaginario de aspectos ciertos de la realidad. Por plasmarse en lo profundo de la conciencia diría que es la parte más significativa de la realidad, y que su lógica, para quien sabe interpretarla, es la más irrebatible, aunque a menudo no exprese el orden verdadero, literal, de los fenómenos. ${ }^{20}$

19. La producción de cestería tiene dos formas: una en la que los patrones no necesitan un diseńo específico, son básicos y sencillos, y sirve para el trabajo cotidiano; y otra en la que los objetos se usan para intercambio o para guardar frutas y casabe. En este caso, los patrones son más complejos y el entramado es doble, lo que otorga una función de estatus al objeto. Tanto lo bidimensional como lo tridimensional hacen parte de un proceso de creación en el que se materializa el pensamiento; sin embargo, ambos responden a condiciones distintas, pues mientras los canastos pueden concebirse como artesanías (el arte que tiene la función de servir a acciones específicas de la comunidad), los dibujos caben en el campo del arte a manera de documentación de la realidad. Si bien en los canastos está presente la visión del mundo, su fabricación responde a necesidades estrictamente pragmáticas. La artesanía es también un reflejo de las acciones sociales que realiza la comunidad.

20. Adolfo Colombres, "Mitos, ritos y fetiches. Desmitificaciones y resignificaciones para una teoría de la cultura y el arte de América", en Hacia una teoría americana del arte, Juan Acha, Adolfo Colombres y Ticio Escobar, eds. (Buenos Aires: Ediciones del Sol, 2004), I87. 


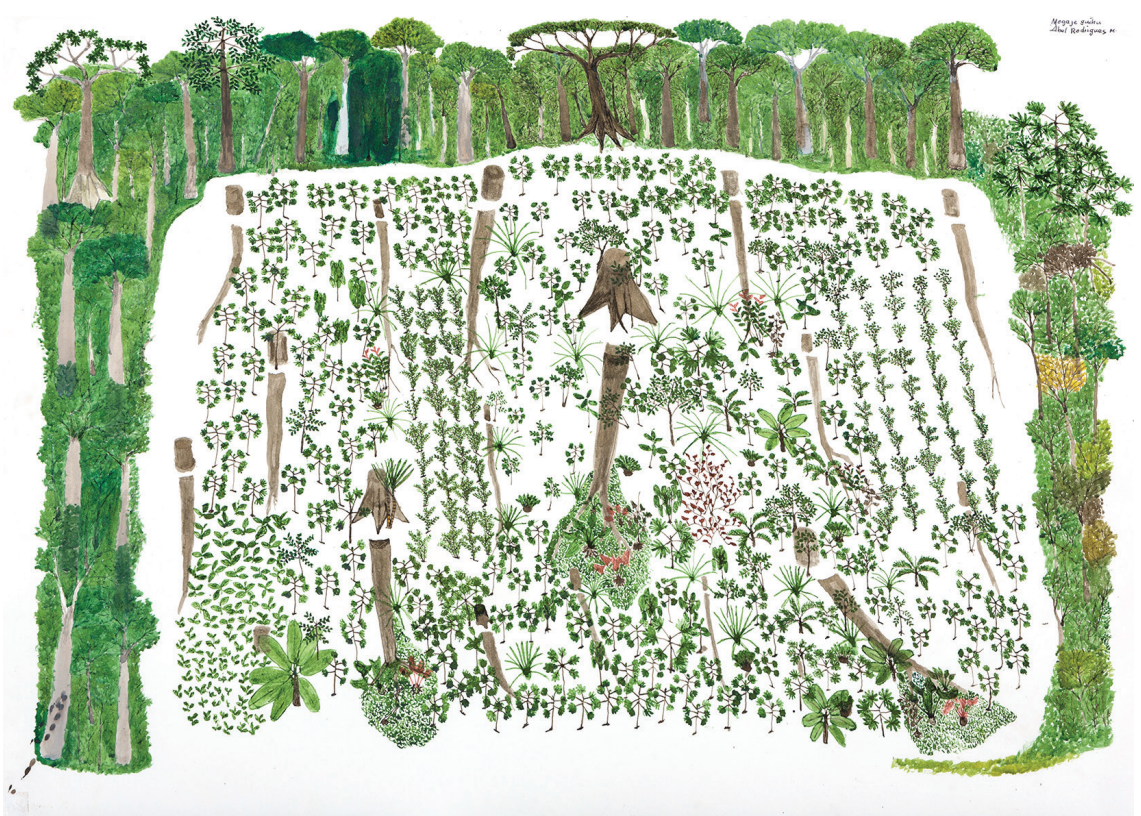

4. Abel Rodríguez, Chagra de seis meses, de la serie Chagra, 2013, tinta china sobre papel, $50 \times 70 \mathrm{~cm}$. Imagen cortesía de Óscar Roldán Alzate.

El papel del mito en el caso que nos ocupa no está exento de tales consideraciones. Rodríguez construye un puente entre el universo de lo simbólico y el de los hechos de la vida cotidiana. Así, lejos de disociar ambas cosas, las integra por medio del arte. Se trata, en definitiva, de una producción visual que pone en evidencia una tensión entre la antropología, el lenguaje y la estética. Para Colombres, el arte, en especial el indígena y el popular, busca reproducir los mecanismos del mito con el fin de perdurar y alcanzar la categoría de patrimonio social. Rodríguez, quizá de manera inconsciente, intenta elaborar sus dibujos mediante tales mecanismos, esto es, de la relación entre las estructuras simbólicas y su simétrica representación de lo sagrado. En esta medida, debe decirse que el arte indígena difícilmente puede tratarse ante los discursos estéticos occidentales, pues lejos de cuestiones formalistas o filosóficas sujetas a la historia de las ideas, las representaciones enuncian su compromiso con la trama total de la comunidad, en la que otras lecturas de la realidad tienen un lugar preeminente. 


\section{Imagen, palabra y memoria: \\ la obra de Abel Rodríguez ante el estado crítico de la lengua nonuya}

Si Rodríguez ha traducido los relatos y mitos originarios de su comunidad en imágenes, una revisión de su obra exige acudir a la relación entre imagen y palabra. Y se puede hacer desde dos ámbitos: del lugar preponderante que ocupan en los estudios recientes de la historia del arte y de la teoría estética las tensiones entre ambos elementos y desde la dimensión simbiótica que adquiere la interrelación imagen-palabra o palabra-imagen en el mundo mítico y físico de los pueblos indígenas.

Respecto del primer aspecto, si bien esa relación es un tema que puede situarse probablemente desde Homero y ha sido visitada desde entonces especialmente por la literatura por medio de la écfrasis, hay que señalar que ante los problemas de la imagen en el arte contemporáneo esta relación adquiere un nuevo valor. La obra artística de Rodríguez bien puede inscribirse en un territorio de confluencias donde el papel de la narración en relación con la imagen ofrece la posibilidad de documentar los saberes y tradiciones, y rescata el panorama cultural de este pueblo indígena. El teórico paraguayo Ticio Escobar sitúa una de las posibilidades de la imagen en el arte contemporáneo en los siguientes términos:

La imagen ocupa un lugar principal en el contexto complicado de la teoría contemporánea del arte. Por un lado, su facultad de moverse por encima de las contradicciones la pone al servicio del conciliador esteticismo globalizado. Por otro, esa misma aptitud le permite vincular presencia y ausencia, desconocer alegremente los límites del arte e iluminar, por un instante, la negra intemperie donde el lenguaje no puede internarse. Estas posibilidades abren opciones políticas a la mirada: la imagen es capaz de zafarse, aun fugazmente, de las dicotomías que inevitablemente sigue promoviendo el lenguaje - forjado en clave metafísica—, tales como las oposiciones entre autonomía y heteronomía estéticas, forma y contenido, signo y cosa, y sujeto y objeto, por citar sólo algunas de las dualidades que escinden el discurso occidental sobre el arte. ${ }^{2 I}$

Por otro lado, aunque las imágenes que crea Abel Rodríguez se encuentran atadas a la narración del mundo que recrean, su función es más que meramen-

2I. Ticio Escobar, Imagen e intemperie (Buenos Aires: Capital Intelectual, 2015), I5. 


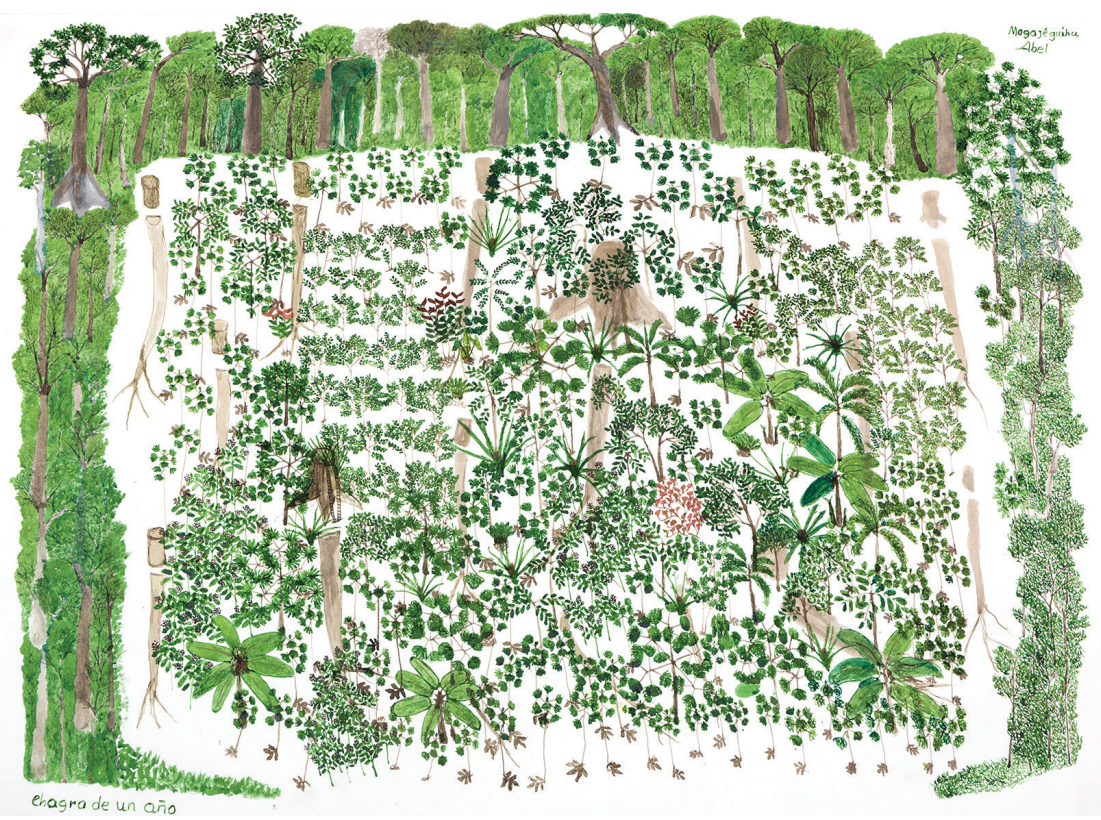

5. Abel Rodríguez, Chagra de un año, de la serie Chagra, 2013, tinta china sobre papel, $50 \times 70 \mathrm{~cm}$. Imagen cortesía de Óscar Roldán Alzate.

te ilustrativa. Sus dibujos, pinturas y canastos no sólo soportan y reafirman el relato que es producto del lenguaje hablado de su pueblo originario, sino que operan como potencia autónoma que es depositaria de un rico universo simbólico: el de la casi extinta nación nonuya. Las creaciones manuales de los pueblos indígenas están determinadas, quizá como en ninguna otra producción humana, por un sentido y trascendencia que se remonta a miles de años atrás hasta los primeros tiempos de la cultura que los produjo. Así, cualquier producto cultural —y podría incluirse también la obra artística de Rodrígueztiene elementos profundos que se ubican en lo más hondo de la historia y la cosmogonía de su pueblo.

Porque para las comunidades indígenas en general -y la suya no es la excepción-cualquier obra manual, como el mencionado canasto, por poner un ejemplo, aparte de su sentido práctico y utilitario para la vida diaria, conlleva eso que el filósofo Fernando Urbina Rangel denomina una "dimensión moral”, que no es otra cosa que aspectos fundamentales de la cultura en la cual 
se inscribe. ${ }^{22}$ Según Urbina, la cuidadosa elaboración de un elemento o utensilio comporta no sólo su eficacia práctica, sino la interiorización del espíritu de la virtud atribuida a ese utensilio por los primeros mitos. De ese modo, su cosmovisión también se traduce en productos y ellos tienen una importancia tal ya que su origen primigenio en el mundo aparece en antiquísimos relatos míticos los cuales se perpetúan en la realización de tales elementos manuales. Y al elaborar cada producto, mediante rituales cotidianos de creación, los antiguos mitos vuelven, se recuerda a los más jóvenes, permanecen en la palabra oral que se pronuncia al momento de su realización y tratan de mantenerse en su historia.

Aun así, las obras de Rodríguez van más allá, incluso, de ser transmisión y conservación del universo nonuya: son un modo de reivindicación de este pueblo y, a la vez, de otros similares que, como el suyo, son poseedores de una rica cosmogonía sometida al olvido, al abandono y al marginamiento tanto por agentes externos como por los propios miembros de la comunidad nonuya que sufren un proceso de aculturación. ${ }^{23}$

Los nonuya o nononota, como también se denominan, han habitado de manera tradicional las riberas del río Cahuinarí, en el departamento colombiano de Amazonas. Pese a que la tradición oral y la historia regional aseguran que constituyeron un grupo poblacional importante, durante la época del auge de la explotación del caucho en la región amazónica (entre finales del siglo XIX $\mathrm{y}$ principios del $\mathrm{xx}$ ) fueron perseguidos, esclavizados y sometidos a toda clase de vejámenes, lo que los llevó a una disminución drástica. ${ }^{24}$ El desplazamien-

22. Fernando Urbina, "El sentido de las creaciones indígenas", en Lenguaje creativo de etnias indigenas de Colombia (Medellín: Grupo de Inversiones Suramericana, 20I2), I5-20.

23. Abel Rodríguez, y consecuentemente su obra, son depositarios de una cosmovisión con valiosos conocimientos sobre el sistema ecosocial de la Amazonía, de un legado construido durante miles de ańos por el pueblo nonuya en el espacio de selva donde ha devenido su existencia. No obstante, este pueblo - es necesario decirlo — está a punto de desaparecer en vista de que su comunidad, compuesta por menos de Ioo personas, ha perdido muchas de sus prácticas sociales y culturales. Y su lengua, uno de los elementos centrales para la transmisión de la cultura, está clasificada por el Ministerio de Cultura de Colombia — como ya se mencionó- como "moribunda". Su preservación es todo un desafío pues "pocas personas la entienden o hablan de manera muy limitada”. Véase Ministerio de Cultura, Gobierno Nacional de Colombia, "Nonuya”, consultado el 23 de julio de 20I6, en www.mincultura.gov.co/areas/poblaciones/APP-de-lenguas-nativas/ Documents/Nonuya.pdf.

24. Una situación idéntica vivieron numerosos pueblos indígenas de esta parte del continente por parte de la tristemente célebre Casa Arana. Y no sólo en ese momento de la historia, sino también posteriormente: en la segunda mitad del siglo xx, los nonuya se vieron obligados a emigrar hacia el río Putumayo y a zonas selváticas del territorio peruano. A eso se sumaron enfermedades 


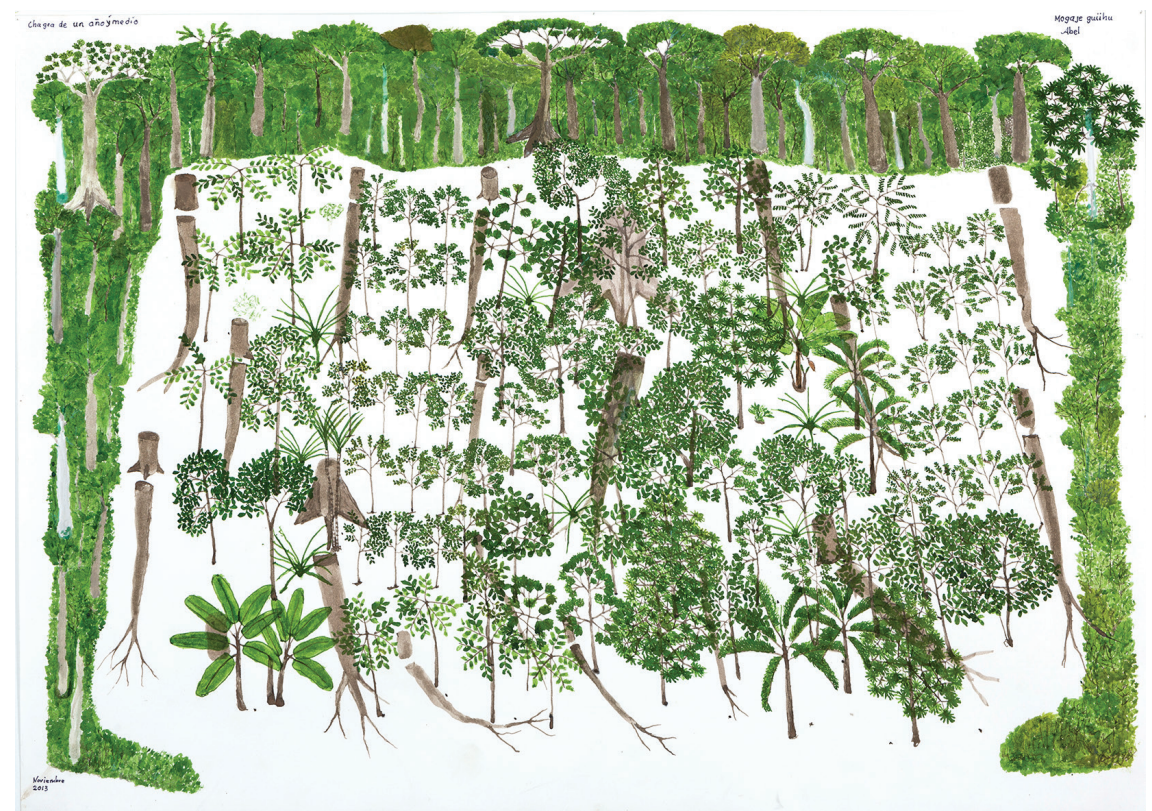

6. Abel Rodríguez, Chagra de año y medio, de la serie Chagra, 2013, tinta china sobre papel, $50 \times 70 \mathrm{~cm}$. Imagen cortesía de Óscar Roldán Alzate.

to del que fueron víctimas y el contacto obligado con otras culturas, incluyendo la de quienes los dominaron, hizo que no sólo su lengua sino otras prácticas y saberes tradicionales se fueran perdiendo con el paso de las generaciones. Todo ello como parte de un proceso violento, pero también sutil el cual, como explica Jacques Guyot, lleva a que "poco a poco, la gente que habla lenguas minoritarias interioriza la dominación y las abandonan". ${ }^{25}$

Estos factores históricos han llevado a que esta lengua originaria, como otras en Colombia y cientos más en todo el mundo, tenga hoy una fragilidad que pone en peligro su pervivencia y la consecuente transmisión de conocimientos producto de interacciones sociales milenarias. Esa situación va debilitando el

y epidemias que contribuyeron a que su población fuera diezmada. Los últimos nonuya viven en la comunidad de Peña Roja, en el corregimiento Puerto Santander, del departamento del Amazonas. Véase "Nonuya".

25. Jacques Guyot, "La diversidad lingüística en la era de la mundialización”, Revista Historia y Comunicación Social, núm. I5 (2010): 59. 


\section{LOPERA GÓMEZ / BETANCUR BETANCUR}

conjunto de elementos que integran su cultura, al punto de llevarla a desaparecer por completo porque la muerte de la lengua madre es un factor central en la desaparición de una cultura. De ahí que la producción artística de Abel Rodríguez sea además un elemento sustancial para, por lo menos, conservar la representación de la cosmovisión nonuya, de sus formas de ver el espacio que ocupan (mediadas obviamente por su percepción individual), de sus prácticas sociales, de sus relaciones con el medio natural que habitan, de su sentido del territorio, en fin, de su modo de habitar el mundo. Entonces, arte y lengua se amalgaman aquí y son a la vez formas de la memoria, especialmente significativas en esta cultura indígena materializada en unas comunidades ya debilitadas por los avatares de la historia.

Lengua y arte, palabra e imagen, son dos elementos de una misma moneda, intrínsecamente relacionados en tanto que ambos son formas para la representación del mundo. En sus "Notas sobre epistemología del lenguaje", Juan Diego Quesada advierte que lengua y arte tienen una función simbolizadora:

Ambos están vinculados por compartir los materiales de que se construyen y por emerger ambos en los mismos contextos históricos. Difieren en grado; esto es, el grado de abstracción para la simbolización entre uno y otro es definitivamente mayor en el arte. Así pues, el artista en tanto sujeto de una colectividad pondría su individualidad, por una parte, y, por otra, la reproducción de la conciencia y de la totalidad de su medio para recrear su realidad y transmitirla representándola por medio de signos y reglas de producción artística en boga en su momento. ${ }^{26}$

Perdida la lengua — como parece que ocurrirá en un periodo aún imposible de determinar con precisión pero que, se cree, será corto- sólo quedarán los vestigios de la lengua misma que hayan sido recogidos en grabaciones como parte de las diferentes investigaciones realizadas por personas y entidades, en las cartillas escolares que se utilizan en las escuelas indígenas, y en las estéticas de los propios objetos y elementos creados en especial por los más viejos de la comunidad, ${ }^{27}$ como Abel Rodríguez. Porque muerto su idioma, prácticamente muere su cultura, como lo explica el antropólogo Wade Davis:

26. Juan Diego Quesada, "Notas sobre epistemología del lenguaje”, Letras I, núms. 23-24 (I99I): 22.

27. María S. González de Pérez, Manual de divulgación de las lenguas indígenas de Colombia (Bogotá: Instituto Caro y Cuervo, 20II). 
Un idioma, desde luego, no es únicamente una serie de reglas gramaticales o un vocabulario. Es un destello del espíritu humano, el vehículo por medio del cual el alma de cada cultura llega al mundo material. Cada idioma es un bosque primitivo de la inteligencia, un hito del pensamiento, un ecosistema de posibilidades espirituales. ${ }^{28}$

Aquí es donde la obra de Rodríguez se constituye además como huella de un pueblo americano originario, en evocación no sólo de la producción material de un ser humano, sino de los más profundos rasgos del ser, pensar, actuar y crear de esta cultura ancestral.

\section{Poscolonialismo y discurso subalterno: nuevas posibilidades para el arte contemporáneo}

Juan Downey tomó en 1976 la fotografía de un indígena yanomami sosteniendo una cámara de video como si estuviera grabando al artista chileno, que en ese momento capturaba una imagen fija por medio de su cámara fotográfica. Esa mirada de vuelta parecía advertir lo que años más tarde fue la inversión del panorama que había dominado las ciencias sociales desde el surgimiento de la antropología y las demás ciencias modernas: ya no se trataba de la mirada fría, externa y científica heredada por las ciencias naturales del siglo xIx. En la fotografía de Downey se trataba de alguien que podía hablar y manifestarse para contribuir a la construcción de conocimiento con una mirada alterna. Desde hace varias décadas en el horizonte de las humanidades y los estudios sociales ha empezado a posicionarse lo que teóricos han denominado como "la voz del subalterno", una manera de construir nuevas narrativas. El historiador, crítico y curador cubano Gerardo Mosquera se refiere así al acontecimiento de Downey y el yanomami:

La imagen representa un desplazamiento de la mirada tomada por el primitivo, el periférico, el objeto habitual de la antropología, quien deviene un sujeto activo. Sin embargo, sólo conocemos la foto tomada por Downey y no la grabación realizada por el yanomami. [...] ¿¿Será posible que hable el subalterno?29

28. Wade Davis, Los guardianes de la sabiduría ancestral: su importancia en el mundo moderno (Medellín: Sílaba, 2015), I4.

29. Mosquera, "Adiós a la antropofagia". 
La pregunta lanzada por Mosquera se toma del texto homónimo escrito por la teórica india Gayatri Chakravorty Spivak en el que se cuestiona el estatus dialógico del subalterno en la narrativa histórica capitalista, es decir, la imposibilidad que tenía el sujeto subalterno de que lo consideraran como un agente discursivo que pudiera hablar o responder en el marco de los grandes relatos. ${ }^{30}$ Esta condición bien podría extrapolarse a los territorios del arte contemporáneo y, en particular, al contexto latinoamericano en un momento en el cual la internacionalización y la multiculturalidad empiezan a cambiar paradigmas establecidos durante gran parte del siglo xx. Para Mosquera, el aumento vertiginoso que han tenido los eventos artísticos en los últimos años, y que responden a realizaciones con periodicidad fija, como en el caso de las bienales y ferias, ha hecho visible a una serie de actores sociales y culturales dentro del panorama internacional que antes o no existían o sólo se limitaban a medios de circulación local. ${ }^{3 \mathrm{I}}$ De este modo, la internacionalización del arte hoy no debe verse únicamente en términos de circuitos, sino también de los discursos que han comenzado a hacerse visibles mediante agentes provenientes de contextos por fuera de los círculos hegemónicos. Tal es el caso de producciones artísticas de algunos países asiáticos, africanos o latinoamericanos. Esto quizá señale una nueva ruta en la producción, presentación y distribución del arte en el panorama internacional, un arte ahora globalizado en el cual las diferencias culturales contribuyen a la pluralidad propia del mundo actual y no a las estructuras de poder jerárquicas que hasta hace unas décadas marcaron los lineamientos para las artes plásticas y visuales. Para el crítico cubano:

Las relaciones entre arte contemporáneo, cultura e internacionalización se han revolucionado en los últimos is años. Hemos dejado atrás los tiempos de los "ismos" y los manifiestos, así como aquellos de los "establishments" centralizados. La cuestión crucial en el arte hoy día es el extraordinario incremento de su práctica y circulación internacional y las implicaciones culturales y sociales de esta expansión..$^{32}$

Las implicaciones sociales y culturales que se derivan de esta nueva dinámica tienen en el reconocimiento de la diferencia uno de sus rasgos principales, en

30. Gayatri Chakravorty Spivak, “¿Puede hablar el subalterno?”, Revista Colombiana de Antropología, núm. 39 (2003): 297-364.

31. Mosquera, "Adiós a la antropofagia".

32. Mosquera, "Adiós a la antropofagia". 
tanto los sujetos que participan de la circulación internacional del arte a su vez se encuentran en constante movimiento físico y cultural, con lo que se quiebra la noción de identidades fijas. Así, la pluralidad, la heterogeneidad y la multiplicidad de los discursos abren nuevos escenarios de discusión alrededor de las manifestaciones estéticas que se movilizan en el mundo del arte. Sin duda alguna se asiste también en el campo de la plástica a las "espumas" señaladas por el filósofo alemán Peter Sloterdijk en su libro Esferas III ${ }^{33}$ donde, mediante una analogía, se refiere al mundo contemporáneo como una serie de escenarios que al mismo tiempo se imbrican unos en otros como si fuera una superficie espumosa en la cual constantemente emergen burbujas, mientras simultáneamente otras revientan. Del mismo modo, los discursos que circundan el arte contemporáneo hacen difusas las estructuras dominantes y la eclosión de nuevos sujetos con sus prácticas discursivas amplía el vasto panorama global del arte, ofreciendo relaciones interculturales y de diálogos disciplinares. Tanto la interculturalidad como la transdisciplinariedad son condiciones presentes en el trabajo de Abel Rodríguez, la primera al entrar en los diálogos recíprocos que ofrecen las exposiciones artísticas, y la segunda en su papel tanto de conocedor botánico como de artista. Podría advertirse que su producción bidimensional comparte entonces características propias del arte contemporáneo, en tanto representación cultural y manifestación estética, que puede inscribirlo de lleno en los circuitos de presentación y distribución artística.

La incorporación de la cosmovisión nonuya en los territorios del arte contemporáneo bien podría verse como una producción visual que supone una condición poscolonial, un cruce de la línea que divide el pensamiento abismal occidental (si se nos permite tomar la expresión de Boaventura de Sousa Santos). Cabe recordar que para De Sousa Santos (2010), la modernidad acentuó una línea "abismal" entre el pensamiento eurocéntrico y el pensamiento de zonas periféricas, al ser este último marginado bajo la perspectiva occidental. ${ }^{34}$ Formas de conocimiento como la nonuya, que durante siglos quedaron "al otro lado de la línea" hoy encuentran un modo de reivindicación epistémica en el campo artístico.

El arte colombiano ha privilegiado por décadas la producción de artistas provenientes de las principales ciudades del país (Bogotá, Cali, Medellín

33. Peter Sloterdijk, Esferas III, trad. Isidora Reguera (Madrid: Siruela, 20I4).

34. Boaventura de Sousa Santos, Para descolonizar Occidente. Más allá del pensamiento abismal (Buenos Aires: Consejo Latinoamericano de Ciencias Sociales-Clacso/Prometeo Libros, 20Io). 
y Barranquilla), dejando de lado el trabajo plástico y visual de artistas pertenecientes a otras zonas periféricas, entre ellos, indígenas. El trabajo de Abel Rodríguez, así como el de otros tantos creadores de pueblos nativos colombianos, revierte esta lógica de circulación de las creaciones estéticas, en tanto ese otro periférico y no visible asume un lugar en el marco de estructuras institucionales: exposiciones, catálogos, artículos de prensa, entre otros. Las imágenes de Rodríguez logran, en este sentido, descolonizar las imágenes que han circulado en el arte colombiano durante al menos la segunda mitad del siglo xx. Cabe recordar en este punto que de acuerdo con Ramón Grosfoguel:

La inferioridad racial de la zona del no-ser ocurre no solamente en relación con los procesos de dominación y explotación en las relaciones de poder económicas, políticas y culturales, sino también en los procesos epistemológicos. El racismo epistémico se refiere a una jerarquía de dominación colonial donde los conocimientos producidos por los sujetos occidentales (imperiales y oprimidos) dentro de la zona del ser es considerada a priori como superior a los conocimientos producidos por los sujetos coloniales no-occidentales en la zona del no-ser. La pretensión es que el conocimiento producido por los sujetos pertenecientes a la zona del ser desde el punto de vista derechista del "Yo" imperial o desde el punto de vista izquierdista del "Otro" oprimido occidental dentro de la zona del ser, es automáticamente considerado universalmente válido para todos los contextos y situaciones en el mundo. Esto conduce a una epistemología imperial/colonial tanto de derecha como de izquierda en el interior de la zona del ser al no tomarse en serio la producción teórica producida desde la zona del no-ser e imponer sus esquemas teóricos pensados para realidades muy distintas a las situaciones de la zona del no-ser. ${ }^{35}$

La situación descrita por Grosfoguel toma lugar en la obra de Abel Rodríguez aquí presentada, toda vez que dentro de la cosmovisión nonuya el relato mítico da cuenta de condiciones geológicas del río Amazonas que hasta ahora explora la ciencia occidental, como la existencia de un río subterráneo o la inversión del curso del río Amazonas después de la emergencia de la cordillera de los Andes. En este caso podría decirse que se trata de una apertura hacia la "ecología de saberes" propuesta por Boaventura de Sousa Santos, donde el

35. Ramón Grosfoguel, "La descolonización del conocimiento: diálogo crítico entre la visión descolonial de Frantz Fanon y la sociología descolonial de Boaventura de Sousa Santos”, en Formas-otras: saber, nombrar, narrar, hacer (Barcelona: СIDOB, 2ОII), IO2. 


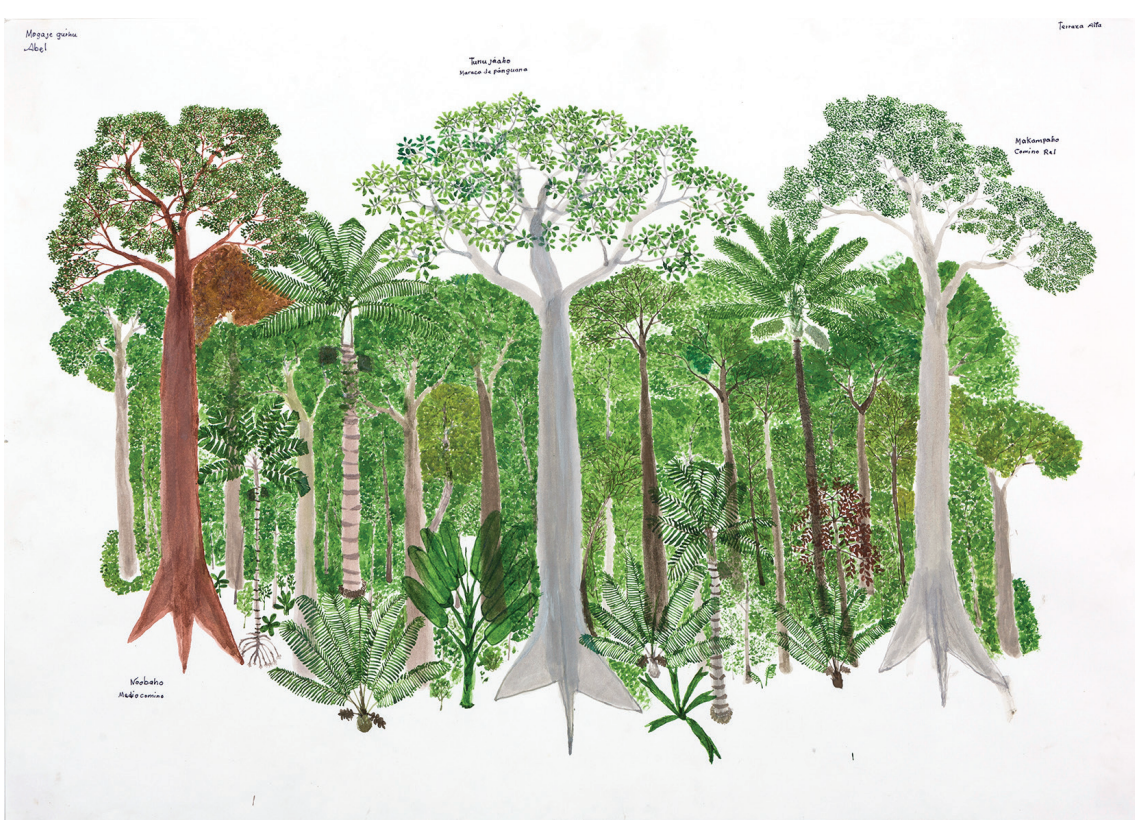

7. Abel Rodríguez, Terraza alta, 20I4, tinta china sobre papel, $50 \times 70 \mathrm{~cm}$. Imagen cortesía de Óscar Roldán Alzate.

saber científico puede entrar en diálogo con el saber indígena. El dibujo, en este caso, es un documento que ilustra un discurso propio de las ciencias naturales, y que soporta un trabajo de campo, nutrido de los conocimientos de Rodríguez, que deriva en una mirada de orden científico (fig. 7). La inclusión del trabajo de Rodríguez en los circuitos de la plástica colombiana permite cuestionar la hegemonía de los centros productores de arte, al hacer evidente un desplazamiento hacia la periferia en la cual se inscriben sectores marginados en lo social, político y cultural.

A la luz de la ecología de saberes y la decolonización epistémica, cabe revisar una de las exposiciones en las que se ha mostrado el trabajo de Rodríguez, para evidenciar el modo en el que las discusiones poscoloniales tienen lugar en el arte contemporáneo desde el ámbito institucional que involucra la circulación y el consumo estético. En 2013 se realizó la versión 43 del Salón Nacional de Artistas en Medellín, la exposición más importante de arte en el país, financiada directamente por el gobierno colombiano por medio del Ministerio de Cultura. En esa ocasión la propuesta curatorial, que dio el título a la versión 
del Salón, se lanzó bajo la premisa "saber desconocer". Con ella se buscaba poner en tensión las certezas arraigadas en las condiciones de producción, distribución y circulación del arte contemporáneo, y las múltiples incertidumbres que puede generar su contraparte, aquella dimensión desconocida que las obras siempre tienen para la experiencia hermenéutica del mundo. En suma, una coexistencia de creencias acerca de lo que se sabe y lo que se desconoce mediante el arte. De acuerdo con la curadora y profesora de la Universidad de Los Andes, Mariángela Méndez, directora artística del Salón:

El Salón revisa los saberes, las tradiciones del territorio y las narrativas que ahí se han generado, y a la vez reconoce una fuerza paralela, el desconocer, que acepta la suspensión de significados unívocos y nos lanza a la duda, a la ambigüedad y a la incertidumbre, lejos de la tradición de un lugar geográfico o una identidad específica. ${ }^{36}$

La obra de Abel Rodríguez expuesta en dos de las sedes del Salón, el Museo de Arte Moderno de Medellín y el Museo de Antioquia, se inscribe en un intersticio que la hace partícipe de ambas líneas de trabajo. Por un lado, puede considerarse como uno de los saberes tradicionales que reivindica la exhibición nacional y, por otro, puede verse como detonador de preguntas acerca de la validez que los relatos menores tienen en la escena artística contemporánea, una obra que incita a la duda, la ambigüedad y la incertidumbre, como bien lo señala Méndez. Tal vez sea necesario, para comprender su papel en el Salón, describir brevemente la manera en que sus obras se dispusieron en ambos espacios de acuerdo con la lógica curatorial. Como se ha dicho antes, en Rodríguez confluyen dos líneas de trabajo que han sido reconocidas por la institucionalidad artística: la primera más cercana a la labor artesanal mediante la elaboración de cestería tradicional nonuya, y la segunda con los dibujos que ha realizado para la Fundación Tropenbos. Ambos trabajos se presentaron en el Salón. Mientras que la cestería se encontraba en la sala sur del Museo de Arte Moderno de Medellín en diálogo con otras producciones de orden artesanal provenientes de indígenas colombianos y brasileños, que hacían explícita su correspondencia con la línea curatorial sobre el "saber", los dibujos se exponían en el Museo de Antioquia en una narración que respondía a la ambigüedad a la que remite "lo desconocido". Respecto a la distribución de las obras, Méndez afirma:

36. Mariángela Méndez, "El Salón en tres actos", en Saber desconocer, 38. 
La estructura dual del Salón también se apoyó en la misma arquitectura de los espacios físicos. Por ejemplo, el Museo de Arte Moderno de Medellín, con sus dos espacios gemelos, ofrecía la disposición para pensar la dicotomía que exhibieron dos muestras colectivas con ideas opuestas, "Destiempo" (lo desconocido) y "Estado oculto" (los saberes). ${ }^{37}$

Así como la obra de Abel Rodríguez, en el Salón se hizo presente la inclusión de trabajos de otros artistas en los que el discurso indígena era inmanente a las obras. Algunos de ellos fueron: Joar Nango, un artista noruego que presentó un archivo musical de hip-hop grabado con miembros de comunidades indígenas desplazadas en la ciudad de Medellín y que traducían la letra de la canción Juicy de Notorious B.I.G. (originalmente en inglés) a la lengua embera-chamí. En el trabajo de este artista noruego ha sido recurrente la referencia a las comunidades nativas en donde trabaja y particularmente la obra que presentó en el Salón hacía parte del proyecto "Land \& Language" que lleva a cabo alrededor del mundo. La intervención sonora estuvo acompañada de grafitis en el espacio público que contenían frases de la canción traducidas por los embera-chamíes y los embera-katíos con quienes trabajó. Otro de los artistas fue Benvenuto Chavajay, que a manera de metáfora sobre el lugar y el arraigo generó un jardín con piedras conectadas con cintas de plástico, haciendo referencia a las transformaciones que sufrieron las comunidades indígenas en la década de los setenta en su estructura social, cultural y antropológica por la llegada del plástico. La artista Johanna Calle (I965) presentó una obra que cuestiona la extinción de las lenguas nativas de Colombia, mediante una serie de 24 dibujos en los que escribía la palabra "agua” en diferentes lenguas indígenas. Finalmente, Mauricio Yekuana, perteneciente al territorio indígena yanomami, presentó una serie de dibujos producto de investigaciones llevadas a cabo por el artista sobre la visualidad yekuana con el fin de preservar y renovar la tradición. Uno de los curadores del Salón, el brasileño Rodrigo Moura, señala la importancia de estos agentes en la exhibición en los siguientes términos:

Fue especialmente relevante incluir artefactos indígenas en la exposición para la yuxtaposición entre campos y objetos construidos en condiciones de producción muy diferentes, pues nos pareció más importante dado el contexto de subexposición de este material y de ausencia total de colecciones públicas permanentes dedicadas a

37. Méndez, "El Salón en tres actos”, 38. 
ello [...]. Tal como el artefacto tuvo lugar en la exposición, incluir la obra de algunos artistas indígenas fue fundamental para abrir las puertas del circuito del arte al pensamiento indígena. ${ }^{38}$

Para Gerardo Mosquera, la internacionalización del arte contemporáneo no debe verse únicamente como un proceso de crecimiento acelerado en los circuitos de producción artística (ferias, bienales, eventos, entre otros), sino también como un fenómeno que ha involucrado la emergencia de prácticas artísticas en regiones donde antes no sucedían. Tal situación corresponde a lo que ha ocurrido en el caso de la obra de Rodríguez (fig. 8). Esto de ningún modo implica el desarrollo de la práctica del arte contemporáneo en una comunidad como la nonuya, más bien se trata de un fiel ejemplo de lo que Mosquera ha denominado como el "fin de la antropofagia". Mediante sus dibujos y los procesos de circulación que ellos han tenido, Abel Rodríguez puede inscribirse dentro de la situación que señala la reivindicación de la voz que hasta ahora se consideraba como subalterna y que hace parte de relatos poscoloniales.

\section{Conclusión}

Con lo presentado hasta este punto llama la atención que en el caso de la obra de Abel Rodríguez sea la voz misma del sujeto oculto la que aparezca en el circuito internacional del arte contemporáneo. Sin embargo, las proporciones deben mantenerse en su justa medida. Como ya se ha dicho en este texto, no ha sido intencional por parte de Rodríguez su integración al mundo del arte, sino que ha sido ese mismo círculo del arte el que ha puesto su trabajo en circulación. No interesa entrar en los detalles de mercado o con fines lucrativos por parte de las instituciones, ésta sería tal vez una discusión que valga la pena abordar en otra ocasión. Más bien, el interés aquí radica en la emergencia de un discurso autóctono, elaborado en una colaboración conjunta entre el pensamiento occidental y el conocimiento tradicional indígena, que ha quedado documentado y se ha hecho visible a través de los circuitos artísticos. La dimensión antropológica del arte, a la luz de los procesos de multiculturalidad permitidos por la globalización, tiene para el teórico español José Luis Brea un

38. Rodrigo Moura, "Estado oculto: movimiento de indigenización en el circuito del arte contemporáneo", Saber desconocer, 96. 


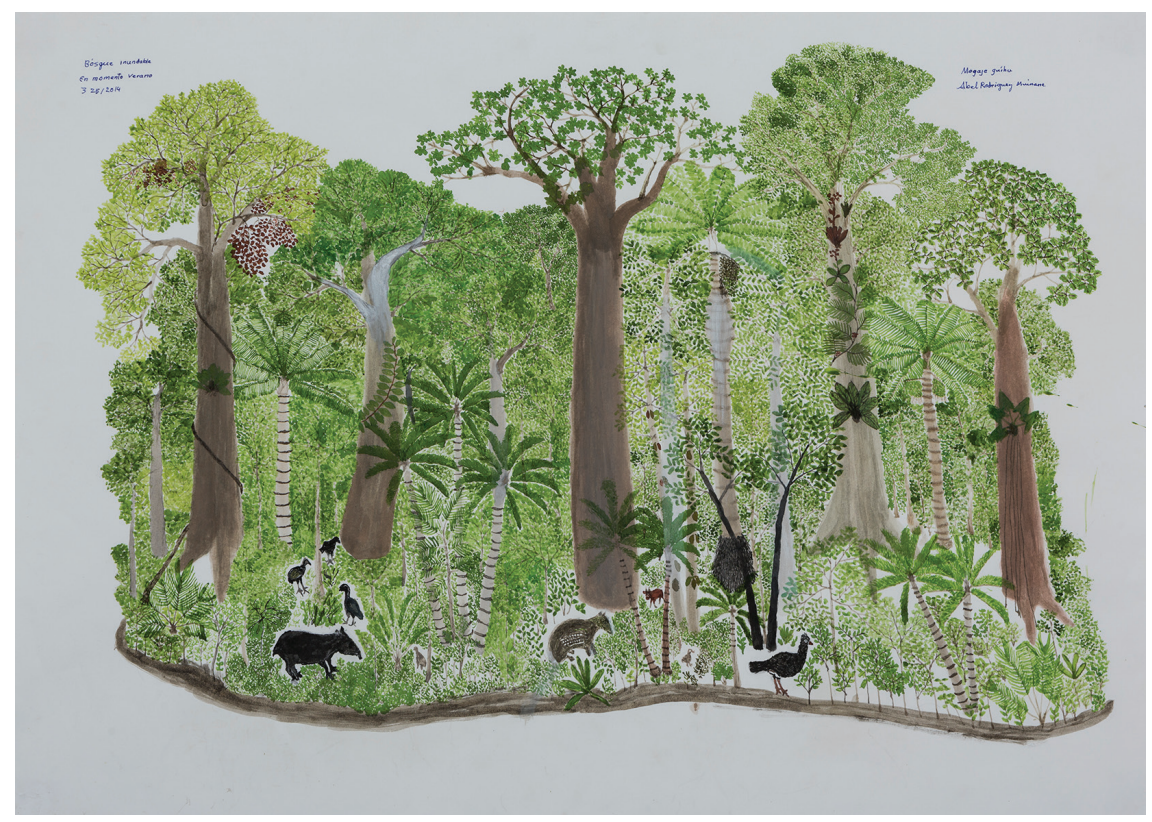

8. Abel Rodríguez, Bosque inundable, 20I4, tinta china sobre papel, $50 \times 70 \mathrm{~cm}$. Imagen cortesía de Óscar Roldán Alzate.

factor determinante en la representación de las comunidades. Se trata del choque cultural que ocurre gracias al aumento del flujo de ciudadanos y de sus respectivos imaginarios y relatos fundantes, particularmente en lo que se refiere a las culturas dominantes. Brea señala:

En un clima de creciente interculturalidad poscolonial, cada una de esas narrativas pierde fuerza de imposición, de recursividad, incluso en — digamos— su propia jurisdicción [...]. El resultado es entonces y para cada una de las culturas que participan en él, un rebajamiento creciente de su fuerza impositiva, de dogma, una creciente y corrosiva relativización de su credibilidad. De ese modo, la que tendía a imponerse como narrativa-fuerza, soi dissant autofundada, pasa ahora inevitablemente a autorreconocerse como una entre las muchas posibles. ${ }^{39}$

39. José Luis Brea, "La muerte del arte y la muerte del arte", en Conflictos interculturales, Néstor García Canclini, ed., Serie Culturas (Barcelona: Gedisa, 20II), 60. 
Cabría preguntarse si la multiculturalidad en el arte contemporáneo abre una posibilidad para que las culturas que se han mantenido al margen de los relatos hegemónicos reivindiquen su presencia en el panorama internacional. ¿Acaso la aparición de pinturas que documentan el conocimiento nonuya no pone en escena una dimensión cultural que escapa a los modelos tradicionales europeos que han intentado colonizar a través de la ilustración o la modernidad el escenario global? Sin duda el discurso cultural que aparece en el circuito artístico con la obra de Rodríguez es un fiel ejemplo de la reivindicación subalterna.

No obstante, debe señalarse que los planteamientos de Mosquera acerca de la antropofagia cultural y la posibilidad de una emergencia de discursos subalternos en el arte contemporáneo se han desarrollado desde principios de la década de los noventa. Habrá de recordarse que una exposición como "Ante América" (1992) curada por Rachel Weiss, Carolina Ponce de León y el mismo Mosquera, ya enunciaba en aquel entonces la posibilidad de pensar Latinoamérica como un constructo meta y multicultural, unido gracias a los lazos geográficos, históricos, económicos y sociales..$^{40}$ Es de notar que la exposición buscó trazar un panorama actual del arte latinoamericano mediante obras que incorporaban discursos identitarios o referencias a su producción cultural. La exposición incluyó el trabajo de artistas afro o nativoamericanos, del Caribe, de comunidades de inmigrantes latinoamericanos en Estados Unidos, de grupos etnoculturales y de artistas en general de diferentes ciudades latinoamericanas. Si bien la intención de incluir artistas de la periferia podría incluso remitirse a algunas de las exposiciones organizadas por el crítico peruano Juan Acha en la década de los ochenta, Ante América constituye, sin duda, uno de los vestigios que evidencia la inclusión de la voz subalterna en el circuito institucional del arte contemporáneo. A más de dos décadas de este suceso, apenas y puede entreverse una apertura real de espacios de circulación y presentación del trabajo de artistas provenientes de comunidades periféricas, en donde claramente se enmarca el objeto de estudio que nos ha ocupado a lo largo de este texto. En esta medida se hacen necesarios más esfuerzos que desde la crítica, la investigación y la curaduría permitan la reivindicación de discursos culturales ausentes en las múltiples narrativas a las que asiste hoy la historia del arte.

El interés por una decolonización epistémica tendría en la situación del trabajo de Abel Rodríguez un punto de análisis que valdría la pena discutir, pues

40. Gerardo Mosquera, Carolina Ponce de León y Rachel Weiss, Ante América (Bogotá: Banco de la República, 1992), io. 
su circulación en los escenarios del arte contemporáneo plantea una cuestión paradójica. Por un lado, se trata de un conocimiento propio de una comunidad indígena que es puesto en circulación por medio de la institucionalidad del arte contemporáneo, exposiciones principalmente, lo que supondría un lugar de enunciación para validar un modo de conocimiento perteneciente a la etnia nonuya. No obstante, el otro lado de la moneda implica ver que tal conocimiento, al insertarse en un medio de circulación como el del arte contemporáneo, tiende en muchos casos, más que a la reivindicación de un conocimiento nativo, a la espectacularización. Ante este panorama resulta más que paradójico situar el problema de la decolonización epistémica, pues a la vez que el conocimiento se preserva al quedar documentado en los dibujos, también se inserta en las dinámicas del mercado del arte. Y así las cosas, el conocimiento de esta etnia nativa difícilmente podría legitimarse en otros espacios de producción intelectual. Este debate lo ha expuesto el filósofo francés Georges DidiHuberman al referirse a los conceptos de sobreexposición y subexposición de los pueblos marginados. ${ }^{4 \mathrm{I}}$ Mientras la primera convierte en espectáculo al subalterno, la segunda lo invisibiliza y lo sigue manteniendo al margen. Así las cosas, podríamos señalar entonces que las tensiones entre centro y periferia, características desde el periodo de la colonia, seguirían acentuándose mediante la dinámica en la que queda inscrito el trabajo de Abel Rodríguez. \$

4I. Georges Didi-Huberman, Pueblos expuestos, pueblos figurantes, trad. Horacio Pons (Buenos Aires: Manantial, 20I4).

N.B. Este artículo es resultado de la investigación "Lenguas nativas de Colombia", financiada por la Dirección de Investigaciones de la Universidad EAFIT durante 20I5. La investigación estuvo a cargo de Juan Gonzalo Betancur Betancur y contó con la participación del Semillero de Producción y Creación Sonora, del pregrado en Comunicación Social de esta universidad, y del estudiante de la maestría en Estudios Humanísticos, Jorge Lopera Gómez. 